\title{
Hubungan Partisipasi dan Kepuasan Masyarakat dalam Program Revitalisasi Kawasan Braga Kota Bandung
}

\author{
Diah Intan Kusumo Dewi, Siti Dea Rakhmania *) \\ Jurusan Teknik Perencanaan Wilayah dan Kota, Fakultas Teknik, Universitas Diponegoro, \\ Jl. Prof. Soedarto, SH, Kampus Undip Tembalang, Semarang, Indonesia 50275
}

\begin{abstract}
Abstrak
Revitalisasi Kawasan Braga sudah dilakukan selama hampir 20 tahun. Namun, masyarakat belum merasa puas dengan revitalisasi yang ada, karena seolah-olah tidak di pertimbangkan dengan matang dan kurang dilibatkannya masyarakat dalam program tersebut. Masyarakat menjadi kurang aktif dalam kegiatan revitalisasi Jalan Braga. Padahal masyarakat yang merasakan dampak dari adanya revitalisasi tersebut. Penelitian ini bertujuan untuk mengetahui hubungan antara tingkat partisipasi dengan kepuasan masyarakat terhadap program revitalisasi. Metode analisis yang digunakan adalah metode analisis kuantitatif dengan teknik analisis deskriptif kuantitatif, skoring dan crosstab. Jumlah Sampel yang digunakan sebanyak 80 sampel. Hasil penelitian ditemukan bahwa tingkat partisipasi masyarakat masih tergolong rendah dengan total skor 1367. Apabila dikaitkan dengan tangga partisipasi Arnstein (1986) partisipasi masyarakat ada pada tahap "Informing”. Sedangkan kepuasan masyarakat tergolong cukup puas dengan skor1717. Berdasarkan hasil penelitian dengan analisis crosstab diketahui hasil chi square test ${ }^{2}(3, N=80)=38.285 ; p<0,05$ atau taraf signifikansinya 0,000 < 0,05 sehingga Ho ditolak dan H1diterima. Hal ini menyatakan ada hubungan antara partisipasi dengan kepuasan masyarakat. Sedangkan berdasarkan hasil uji kolerasi maka diketahui $r(80)=0.637 ; p>0.01$ dan $r(80)=0.682 ; p>0.01$ yang artinya hubungan antar variable tergolong kuat. Berdasarkan koefisien kolerasinya maka diketahui bahwa hubungan antar variabel memiliki hubungan yang positif.
\end{abstract}

Kata kunci: Revitalisasi; partisipasi masyarakat; kepuasan masyarakat, Braga

\begin{abstract}
[Correlation between Community Participation and Community Satisfaction in Revitalization Program at Braga Street, Bandung] Braga revitalization has already been done for almost 20 years. Nevertheless, people there still feel dissatisfied because it is not carefully considered as though and lack of participation in revitalization program. Whereas, people around are those who affected by revitalization program. This research aims to learn about correlation between participation level and satisfaction level towards the program. The analysis method used in this research is quantitative analysis by quantitative descriptive, scoring, and crosstab technique. Number of samples used in this research are 80 samples. Meanwhile, the result found is that level of community participation considered in a low level with score 1367. When associated with Arnstein's participation ladders, the level of community participation is on informing stage. Whilst, the research's result about level of community satisfaction is considered in a quite satisfied level with score 1717. Based on the crosstab analysis, known that the result of chi-square test ${ }^{2}(3, N=80)=38.285 ; p<0.05$ or significance degree is $0.000<0.05$ so $H_{o}$ rejected and $H_{1}$ accepted. It is stated that there is a correlation between participation and community satisfaction. While, based on correlation test, known that $r(80)=0.637 ; p>0.01$ and $r(80)=0.682 ; p>0.01$ which means the correlation considered in a strong level and correlation coefficient has a positive relation.
\end{abstract}

Keywords: Revitalization; community participation; community satisfaction, Braga

\footnotetext{
${ }^{*}$ Penulis Korespondensi.

E-mail: dearakhmania@gmail.com
} 
Teknik, 37 (1), 2016, 18

\section{Pendahuluan}

Revitalisasi merupakan upaya untuk meningkatkan kembali vitalitas suatu kawasan melalui peningkatan lingkungan atau peningkatan pengembangan kegiatan sosial, tanpa menimbulkan perubahan yang berarti dari struktur fisik kawasan tersebut. Revitalisasi dalam Piagam Burra (1981) dinyatakan sebagai upaya merubah tempat agar dapat digunakan untuk fungsi yang lebih sesuai, yaitu kegunaan yang tidak menuntut perubahan drastis atau hanya melakukan sedikit perubahan.

Menurut Katam (2010) seorang peneliti Kota Bandung, revitalisasi dimulai pada tahun 1980-an dilaksanakan oleh Pemkot Bandung dengan menjadikan Kawasan Braga sebagai area Pameran Produksi Jawa Barat, tetapi kegiatan tersebut tidak berlanjut ke tahun berikutnya (Gambar 1 dan 2) (news.detik.com, 2010). Tahun 1998-an digelar acara bertajuk Braga Kaget dan Festival Bunga Braga. Tahun 2000, muncul isu akan dikembangkanya Jalan Braga menggunakan konsep yang diterapkan di Kembang Jepun (Surabaya) atau Jalan Malioboro (Yogyakarta). Kemudian direalisasikan dengan melakukan pelebaran trotoar kemudian di sepanjang kedua sisi Jalan Braga (di sisi luar trotoar) ditanami pohon Karet Benggol.

Tahun 2004 Pemerintah Kota Bandung kemudian membuat kebijakan baru dalam revitalisasi di Kawasan Braga. Bentuk revitalisasi yang dicanangkan oleh pemkot dan pihak pengembang adalah dengan pembangunan Braga City Walk (BCW). Tahun 2005 event Braga Festival kembali digelar setelah sempat tidak dilaksanakan dari tahun 1960-an. Tahun 2007 dilakukan pelebaran trotoar selebar 0.5 meter serta penanaman 81 tanaman hias dan penggantian lampu hias. Tahun 2008 revitalisasi dilakukan pada upaya pengembalian arsitektural bangunan dengan pengecatan bangunan, penataan reklame dan penggantian material perkerasan jalan dengan menggunakan batu andesit.

Revitalisasi Jalan Braga pun kembali digencarkan di tahun 2014 hal ini dikarenakan Jalan Braga akan menjadi bagian dari acara Konferensi Asia Afrika pada tahun 2015. Oleh karena itu, selain melakukan perbaikan di Jalan Asia Afrika, Jalan Braga pun kembali dibenahi. Perbaikan yang dilakukan oleh Pemerintah Kota Bandung adalah dengan memperbaiki saluran air dengan pemasangan blok cluvert, pengantian trotoar dengan menggunakan batu granit bakar, selain itu juga dilakukan pemasangan bangku, pengecetan seluruh bangunan, pemasangan bunga hias, penggantian lampu hias dan pemasangan batu hias di sepanjang jalan Braga. Pemerintah Kota Bandung juga melaksanakan suatu event yang digelar setiap 2 minggu sekali yaitu Braga Culinary Night $(\mathrm{BCN})$.

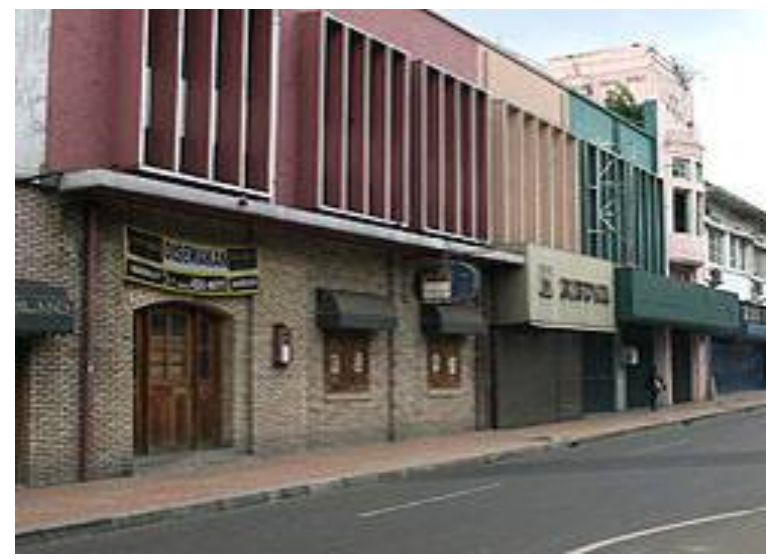

Gambar 1. Pedestrian Jalan Braga sebelum perbaikan di tahun 2000 (news.detik.com, 2010)

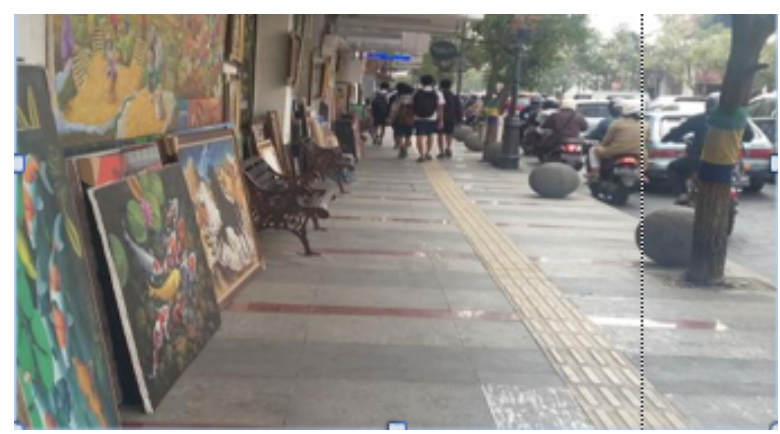

Gambar 2. Pedestrian Jalan Braga setelah perbaikan di tahun 2015 (Dokumentasi Pribadi, 2015)

Revitalisasi di tahun 2004 dengan pembangunan Braga City Walk (BCW) masih menjadi perdebatan dengan masyarakat menurut Ketua RT 4 RW 8 beberapa masyarakat di belakang BCW mengeluhkan kurangnya sinar matahari karena tertutupi bangunan gedung yang tinggi, susahnya pasokan air karena sumur kering dan udara pengap (Syahrie, 2010). Sampai saat ini, masyarakat hanya bisa pasrah dengan keadaan yang ada. Telatnya perbaikan trotoar dan saluran air di tahun 2014 membuat sejumlah warga dan wisatawan mengeluhkan kenyamanan Jalan Braga, Udara sekitar berdebu dan pecahan keramik berserakan di trotoar sehingga mengganggu pejalan kaki. Para pedagang mengeluhkan selalu adanya perbaikan terus menerus di Jalan Braga, terutama sejak di digantinya perkerasan jalan menggunakan batu andesit di tahun 2009. Hampir setiap tahun jalan mengalami kerusakan sehingga harus selalu diperbaiki. Hal tersebut membuat masyarakat terutama pedagang yang mengalami penurunan omset hampir 50\% saat dilakukannya perbaikan di Jalan Braga. Masyarakat menjadi kurang puas dengan revitalisasi yang ada karena seolah olah tidak di pertimbangkan dengan matang.

Banyaknya keluhan masyarakat dan kurang puasnya masyarakat akan beberapa program revitalisasi yang ada memunculkan dugaan kurang dilibatkannya masyarakat dalam program revitalisasi 
yang sudah bertahun-tahun dilaksanakan. Sehingga program revitalisasi yang dilaksanakan tersebut belum sesuai dengan kebutuhan masyarakat. Penelitian ini bertujuan untuk mengetahui hubungan antara tingkat partisipasi masyarakat dengan kepuasan masyarakat terhadap program revitalisasi.

\section{Metode Penelitian}

Penelitian dilakukan dengan menganalisis informasi kuantitatif (data yang dapat diukur, diuji dan diinformasikan dalam bentuk seperti persamaan, tabel dan sebagainya), menggunakan model-model hitungan statistik yang diiringi dengan teori atau hipotesis yang berkaitan dengan suatu fenomena (Hediansyah, 2010). Pendekatan kuantitatif ini dibutuhkan variabelvariabel penelitian yang sesuai dengan substansi yang akan diteliti.

\subsection{Teknik Pengumpulan Data}

Pada penelitian ini, teknik yang digunakan dalam pengumpulan data primer adalah dengan melakukan observasi lapangan, wawancara dengan berbagai stakeholder yaitu tokoh masyarakat dan lembaga terkait, dan penyebaran kuisioner atau angket kepada objek penelitian. Sedangkan pengumpulan data sekunder dilakukan dengan melakukan survei instansi dan studi literatur atau dokumen terkait pembahasan penelitian.

\subsection{Teknik Sampling}

Pengumpulan data dengan metode wawancara memiliki beberapa sampel yang berhubungan erat dengan kegiatan revitalisasi yang dilakukan di Kawasan Braga, terutama dinas-dinas yang menangani langsung penataan dan Revitalisasi Kawasan Braga (Tabel 1).

Selain dengan melaukan wawancara penelitian juga menggunakan kuesioner sebagai salah satu alat pengumpul data. Mengingat ruang lingkup wilayah yang besar, peneliti hanya perlu mengambil beberapa responden yang dijadikan sebagai sampel. Responden kuesioner ini ditujukan kepada masyarakat yang terdiri dari 2 golongan masyarakat yang telah dijelaskan sebelumnya yaitu pedagang di sekitar Kawasan Braga serta masyarakat Kawasan Braga yaitu RW 4, 6 dan 8. Pengambilan sampel prioritas dilakukan kepada penduduk yang tergolong pada usia produktif yaitu 20-54 tahun. Serta penduduk yang tinggal $>5$ tahun di Kawasan Braga.

Untuk penentuan jumlah sampel pedagang dilakukan dengan menggunakan teknik random sampling yang digunakan adalah nonprobability sampling dengan jenis accidental sampling. Teknik random sampling yang dilakukan pada Jalan Braga memiliki asumsi bahwa rata-rata jumlah pedagang yang berjualan pada pagi-sore hari berjumlah 25 pedagang. Maka jumlah sampel kuesioner adalah 15 kuesioner.
Tabel 1. Responden Wawancara (Hasil Analisis Peneliti, 2015)

\begin{tabular}{|c|c|}
\hline $\begin{array}{l}\text { Sumber Data/ } \\
\text { Informasi }\end{array}$ & Target Informasi \\
\hline $\begin{array}{l}\text { Bappeda Kota } \\
\text { Bandung }\end{array}$ & $\begin{array}{l}\text { RTRW Kota Bandung, Roadmap } \\
\text { Bandung Juara, }\end{array}$ \\
\hline $\begin{array}{l}\text { Dinas Tata Ruang } \\
\text { dan Cipta Karya }\end{array}$ & $\begin{array}{l}\text { Proses revitalisasi dari tahun ke } \\
\text { tahun, perubahan penggunaan } \\
\text { lahan, perubahan fungsi bangunan, } \\
\text { dan RencanaTata Bangunan } \\
\text { Ligkungan (RTBL) }\end{array}$ \\
\hline $\begin{array}{l}\text { Dinas PU Kota } \\
\text { Bandung }\end{array}$ & $\begin{array}{l}\text { Program revitalisasi, tahun } \\
\text { pelaksanaan, hasil pelaksanaan, } \\
\text { dampak, kendala yang dihadapi } \\
\text { dan rencana perbaikan kedepannya. }\end{array}$ \\
\hline Kelurahan Braga & $\begin{array}{l}\text { Proses pelaksanaan revitalisasi, } \\
\text { proses pelibatan masyarakat dalam } \\
\text { revitalisasi, dampak yang } \\
\text { ditimbulkan, dan permasalahan } \\
\text { yang ada saat proses revitalisasi }\end{array}$ \\
\hline $\begin{array}{l}\text { Bandung Haritage } \\
\text { Society }\end{array}$ & $\begin{array}{l}\text { Kontribusi LSM dalam proses } \\
\text { revitalisasi, kerjasama LSM dengan }\end{array}$ \\
\hline & $\begin{array}{l}\text { pemerintah, Kerjasama LSM } \\
\text { dengan Masyarakat }\end{array}$ \\
\hline Galur Braga & $\begin{array}{l}\text { Kontribusi LSM dalam proses } \\
\text { revitalisasi, kerjasama LSM dengan }\end{array}$ \\
\hline & $\begin{array}{l}\text { pemerintah, Kerjasama LSM } \\
\text { dengan Masyarakat }\end{array}$ \\
\hline $\begin{array}{l}\text { Masyarakat Peduli } \\
\text { Braga }\end{array}$ & $\begin{array}{l}\text { Kontribusi LSM dalam proses } \\
\text { revitalisasi, kerjasama LSM dengan }\end{array}$ \\
\hline & $\begin{array}{l}\text { pemerintah, Kerjasama LSM } \\
\text { dengan Masyarakat }\end{array}$ \\
\hline $\begin{array}{c}\text { Ketua RW 4,6 dan } \\
8\end{array}$ & $\begin{array}{l}\text { Proses pelaksanaan revitalisasi, } \\
\text { proses pelibatan masyarakat dalam }\end{array}$ \\
\hline & $\begin{array}{l}\text { revitalisasi, dampak yang } \\
\text { ditimbulkan, dan permasalahan } \\
\text { yang ada saat proses revitalisasi }\end{array}$ \\
\hline
\end{tabular}

Sedangkan untuk penentuan sampel kuesioner masyarakat sekitar dengan menggunakan menggunakan stratifiled random sampling. Rumus yang digunakan dalam teknik sampling ini (Nazir,1999) adalah :

$$
n=\frac{N Z^{2} p(1-p)}{N G^{2}+Z^{2} p(1-p)}
$$

dalam hubungan ini, n: Jumlah sampel; N: Jumlah populasi; Z: Tingkat kepercayaan (dari tabel t dengan $\mathrm{df}=\sim$ dan level signifikansi $=0,10)=1,645 ; \mathrm{P}$ : Proporsi $=0,5$; dan G: Galat pendugaan, yang diambil $10 \%$ dengan tingkat kecermatan studi tergolong cermat

Populasi untuk wilayah penelitian yaitu RW 4, 6 dan 8 tahun 2013 berjumlah 2458 jiwa (Monografi Kelurahan Braga, 2014), sehingga sampel yang diambil sebanyak $\mathrm{n}$.

$$
n=\frac{(2458)(1,645)^{2} \times 0,5(1-0,5)}{(2458)(0,1)^{2}+(1,645)^{2} \times 0,5(1-0,5)}=65
$$


Teknik, 37 (1), 2016, 20

\subsection{Teknik Analisis Data}

Metode yang digunakan adalah metode kuantitatif. Metode ini digunakan untuk menganalisis informasi kuantitatif. Analisis yang digunakan dalam penelitian ini diantaranya analisis deskriptif, analisis scoring dengan likert scale, analisis cross tab dan uji Kolerasi Spearman's Rho dan Kendall's Tau. Metode deskriptif merupakan metode dengan cara menuturkan dan menafsirkan data yang ada (Surakhmad, 1980). Analisis deskriptif ini digunakan untuk melakuakan mengetahui proses revitalisasi yang ada di Kawasan Braga sesuai dengan variable penelitiannya. Kemudian dianalisis secara deskriptif dengan menggunakan tabel atau diagram.

Analisis lainnya yang digunakan adalah analisis scoring dengan likert scale. Skala Likert digunakan untuk mengukur sikap, pendapat dan persepsi seseorang atau kelompok tentang suatu penelitian. Variabel yang akan diukur dijabarkan menjadi indikator variabel. Kemudian indikator tersebut dijadikan item untuk menyusun item-item instrumen yang berbentuk pertanyaan atau pernyataan (Sugiyono, 2005). Skala Likert tersebut menunjukkan interpretasi : sangat setuju diberi skor 5 , setuju diberi skor 4, netral/ragu-ragu diberi skor 3, tidak setuju diberi skor 2, sangat tidak setuju diberi skor 1 (Sugiyono, 2005). Setelah melakukan scoring maka kemudian dilakukan analisis dengan menggunakan tipologi berdasarkan delapan tangga partisipasi Arnstein (1986). Arnstein menyatakan bahwa partisipasi masyarakat identik dengan kekuasaan masyarakat (citizen participation is citizen power). Partisipasi masyarakat bertingkat sesuai dengan gradasi kekuasaan yang dapat dilihat dalam proses pengambilan keputusan. Terdiri dari delapan tipologi diantaranya adalah manipulation, therapy, informing, consultation, placation, partnership, delegeted power dan citizen control.

Kemudian untuk mengetahui hubungan antara variable digunakan analisis dengan menggunakan cross tab (tabulasi silang). Tabulasi silang adalah prosedur yang digunakan untuk mengetahui kombinasi nilai-nilai yang berbeda dari dua variabel atau lebih dengan menghitung harga-harga statistik beserta ujinya. Metode tabulasi silang yang akan mentabulasikan beberapa variabel yang berbeda ke dalam suatu matriks, hasil tabulasi silang disajikan dalam bentuk suatu tabel dengan variabel-variabel yang tersusun sebagai kolom dan baris tabel tersebut dengan menggunakan SPSS. Hasil yang dapat diketahui adalah nilai Chi Square. Selanjutnya nilai Chi Square akan dibandingkan dengan nilai $\mathrm{X}^{2}$ tabel. Nilai $\mathrm{X}^{2}$ tabel yang dipergunakan dalam penelitian ini adalah nilai $\mathrm{X}^{2}$ tabel dengan $\mathrm{df}=3$. Adapun ketentuan dalam pembuktian adanya hubungan antara bentuk partisipasi dengan kondisi sosial ekonomi adalah : Jika $\mathrm{X}^{2}$ hitung $<\mathrm{X}^{2}$ tabel $(\mathrm{df} \mathrm{k-1} \times \mathrm{k}-1)=2, \mathrm{H} 0$ : diterima; dan Jika $\mathrm{X}^{2}$ hitung $>\mathrm{X}^{2}$ tabel $(\mathrm{df} \mathrm{k}-1 \mathrm{x}$ k-1) $=2$, H1 : diterima (H0 ditolak). Selanjutnya untuk mendukung hasil yang didapatkan dari analisis tabulasi silang maka dilakukan Uji Kolerasi Spearman's Rho dan Kendall's Tau. Keduanya cenderung memberikan hasil signifikan yang sama. Perbedaan keduanya hanya terletak pada rumus perhitungannya. (Sufren dan Yonathan Natael, 2014).

\section{Hasil dan Pembahasan}

\subsection{Proses Revitalisasi Kawasan Braga}

Sejak awal abad ke-20, hingga akhir tahun 70an Jalan Braga di Kota Bandung merupakan pusat perniagaan modern yang sangat populer. Jalan Braga menjadi bukti nyata masa kejayaan Parijs Van Java dalam bidang ekonomi (1920-1930). Citra yang melekat pada jalan Braga kala itu sangat kuat sehingga dijuluki De Meest Europeeschen Winkelstraat van Indie (Kompleks pertokoan Eropa yang paling terkemuka di Hindia Belanda). Sehingga menjadi salah satu Central Busniess District pada masa itu.

Secara geografis Kelurahan Braga Kecamatan Sumur Bandung memiliki bentuk wilayah yang datar sebesar $21 \%$ dari total keseluruhan luas wilayah. Kelurahan Braga jika ditinjau dari sudut ketinggian tanah, berada pada ketinggian 650 meter diatas permukaan air laut. Sebagian besar kawasannya merupakan kawasan permukiman padat penduduk dan disekitar Jalan Braga merupakan kawasan Perdagangan dan Jasa.

Pasca kemerdekaan kawasan Braga mengalami kemunduran aktivitas perdagangan akibat banyaknya berbagai intervensi sehingga daya tarik kawasan tersebut memudar. Menurut Budiman (2002) kemunduran ini terjadi terutama sejak kemunculan pusat perbelanjaan modern pada tahun 1980-an. Gambar 3 dan Tabel 2 menggambarkan fakta-fakta proses revitalisasi Kawasan Braga.

\subsection{Analisis Partisipasi Masyarakat}

Tingkat Partisipasi masyarakat dalam analisis ini diukur dengan menggunakan metode kuantitatif dengan menggunakan Skala Likert (Riduwan, 2004:88). Dengan menggunakan Skala Likert, dapat diketahui skor masing-masing indikator dari variabel yang didapatkan dari jawaban responden, sehingga tingkat partisipasi dapat diketahui melalui total skor secara keseluruhan dari seluruh variabel. Total reponden dalam penelitian ini adalah sebanyak 80 responden sebanyak 65 orang merupakan masyarakat sekitar Braga (RW 4, 6 dan 8) dan 15 orang merupakan pedagang di Jalan Braga. Juga terdiri dari 30 responden wanita dan 50 responden pria.

Tabel 3 menjelaskan tentang hasil pilihan responden terhadap 10 kategori dengan masingmasing 3 indikatornya yang menyangkut tingkat partisipasi masyarakat, maka secara kuantitatif dapat diketahui tingkat partisipasi masyarakat tersebut dengan menjumlahkan skor masing-masing indikator yang didapatkan dengan mengalikan skala masingmasing dengan frekuensi jawaban responden. 
Teknik, 37 (1), 2016, 21

Tabel 2 Proses Revitalisasi Kawasan Braga Kota Bandung (Hasil Analisis Peneliti, 2015)

\begin{tabular}{|c|c|c|c|c|}
\hline $\begin{array}{c}\text { Tahun } \\
\text { Pelaksanaan }\end{array}$ & Program & Stakeholders & Partisipasi Masyarakat & Keterangan \\
\hline 1980-an & $\begin{array}{l}\text { Pameran Produksi Jawa } \\
\text { Barat }\end{array}$ & $\begin{array}{l}\text { Pemerintah Prov. Jawa } \\
\text { Barat }\end{array}$ & $\begin{array}{l}\text { Hanya pemberian } \\
\text { informasi }\end{array}$ & $\begin{array}{l}\text { Tidak dilanjutkan ditahun } \\
\text { selanjutnya }\end{array}$ \\
\hline \multirow[t]{2}{*}{1998} & Braga Kaget & $\begin{array}{l}\text { Pemerintah Kota Bandung } \\
\text { (Dinas Pariwisata Kota } \\
\text { Bandung) }\end{array}$ & $\begin{array}{l}\text { Hanya pemberian } \\
\text { informasi }\end{array}$ & $\begin{array}{l}\text { Tidak dilanjutkan ditahun } \\
\text { selanjutnya }\end{array}$ \\
\hline & Festival Bunga Braga & $\begin{array}{l}\text { Pemerintah Kota Bandung } \\
\text { (Dinas Pariwisata Kota } \\
\text { Bandung) }\end{array}$ & $\begin{array}{l}\text { Hanya pemberian } \\
\text { informasi }\end{array}$ & $\begin{array}{l}\text { Tidak dilanjutkan ditahun } \\
\text { selanjutnya }\end{array}$ \\
\hline \multirow[t]{2}{*}{2000} & Perbaikan trotoar & $\begin{array}{l}\text { Pemerintah Kota Bandung } \\
\text { (Dinas PU dan Dinas } \\
\text { Pemakaman dan } \\
\text { Pertamanan) }\end{array}$ & $\begin{array}{l}\text { Hanya pemberian } \\
\text { informasi }\end{array}$ & $\begin{array}{l}\text { Perbaikan trotar demi menunjang } \\
\text { konsep City Walk }\end{array}$ \\
\hline & $\begin{array}{l}\text { Penanaman vegetasi di } \\
\text { sepanjang sisi jalan. }\end{array}$ & $\begin{array}{l}\text { Pemerintah Kota Bandung } \\
\text { (Dinas PU dan Dinas } \\
\text { Pemakaman dan } \\
\text { Pertamanan) }\end{array}$ & $\begin{array}{l}\text { Masyarakat ikut membantu } \\
\text { dalam proses penanaman }\end{array}$ & Penanaman pohon Karet Benggol \\
\hline 2004 & $\begin{array}{l}\text { Pembangunan Braga } \\
\text { City Walk }\end{array}$ & $\begin{array}{l}\text { Pemerintah Kota Bandung } \\
\text { bekerja sama dengan PT } \\
\text { Bangun Mitra Mandiri } \\
\text { (BMM) anak perusahaan } \\
\text { Grup Agung Podomoro }\end{array}$ & $\begin{array}{l}\text { Pemerintah bersama LSM } \\
\text { Bandung Haritage Society } \\
\text { dan Distarcip merumuskan } \\
\text { suatu masterplan penataan } \\
\text { ruang }\end{array}$ & $\begin{array}{l}\text { Pembangunan hotel apartemen } \\
\text { dan mall ini memiliki tinggi } 15 \\
\text { lantai, } 3 \text { lantai area shopping } \\
\text { center dan } 4 \text { lantai basement }\end{array}$ \\
\hline 2005 & Braga Festival & $\begin{array}{l}\text { Pemerintah Kota Bandung } \\
\text { (Dinas Pariwisata Kota } \\
\text { Bandung) }\end{array}$ & $\begin{array}{l}\text { Masyarakat ikut dilibatkan } \\
\text { sebagai panitia } \\
\text { penyelenggara }\end{array}$ & $\begin{array}{l}\text { Dilaksanakan setiap tahun rutin } \\
\text { di bulan Desember }\end{array}$ \\
\hline \multirow[t]{2}{*}{2007} & Pelebaran Trotoar & $\begin{array}{l}\text { Pemerintah Kota Bandung } \\
\text { (Dinas PU dan Dinas } \\
\text { Pemakaman dan } \\
\text { Pertamanan) }\end{array}$ & $\begin{array}{l}\text { Tidak ada partisipasi } \\
\text { masyarakat }\end{array}$ & Pelebaran dengan lebar $0,5 \mathrm{~m}$ \\
\hline & $\begin{array}{l}\text { Penanaman tanaman } \\
\text { hias }\end{array}$ & $\begin{array}{l}\text { Pemerintah Kota Bandung } \\
\text { (Dinas PU dan Dinas } \\
\text { Pemakaman dan } \\
\text { Pertamanan) }\end{array}$ & $\begin{array}{l}\text { Masyarakat ikut membantu } \\
\text { dalam proses penanaman }\end{array}$ & Penanaman 81 tanman hias \\
\hline \multirow[t]{3}{*}{2008} & $\begin{array}{l}\text { pengembalian bentuk } \\
\text { arsitektural bangunan }\end{array}$ & $\begin{array}{l}\text { Pemerintah Kota Bandung } \\
\text { (Dinas Tata Ruang dan } \\
\text { Cipta Karya) }\end{array}$ & $\begin{array}{l}\text { Masyarakat(pemilik toko) } \\
\text { menjadi pelaku utama } \\
\text { dalam pelestarian } \\
\text { bangunan tua }\end{array}$ & $\begin{array}{l}\text { Dilakukan pengecetan terhadap } \\
\text { bangunan sepanjang jalan Braga }\end{array}$ \\
\hline & penataan reklame & $\begin{array}{l}\text { Pemerintah Kota Bandung } \\
\text { (Dinas Tata Ruang dan } \\
\text { Cipta Karya) }\end{array}$ & $\begin{array}{l}\text { Hanya pemberian } \\
\text { informasi }\end{array}$ & $\begin{array}{l}\text { Menghasilkan kebijakan terkait } \\
\text { pemasangan reklame }\end{array}$ \\
\hline & $\begin{array}{l}\text { penggantian meterial } \\
\text { perkerasan jalan }\end{array}$ & $\begin{array}{l}\text { Pemerintah Kota Bandung } \\
\text { (Dinas Pekerjaan Umum) }\end{array}$ & $\begin{array}{l}\text { Hanya pemberian } \\
\text { informasi }\end{array}$ & $\begin{array}{l}\text { Penggantian perkerasaan dari } \\
\text { aspal menjadi batu andesit. } \\
\text { Namun Belum genap satu tahun } \\
\text { selesai, kontruksi Jalan Braga } \\
\text { sudah berantakan, bergelombang } \\
\text { dan mengalami kerusakan }\end{array}$ \\
\hline 2009 & $\begin{array}{l}\text { Pembangunan Hotel } \\
\text { Gino Feruci }\end{array}$ & $\begin{array}{l}\text { Pengembang swasta dengan } \\
\text { izin Pemkot Bandung }\end{array}$ & $\begin{array}{l}\text { Hanya pemberian } \\
\text { informasi }\end{array}$ & Selesai di bangun tahun 2012 \\
\hline \multirow[t]{5}{*}{2014} & $\begin{array}{l}\text { Perbaikan Trotoar dan } \\
\text { saluran air }\end{array}$ & $\begin{array}{l}\text { Pemerintah Kota Bandung } \\
\text { (Dinas PU) }\end{array}$ & $\begin{array}{l}\text { Masyarakat ikut membantu } \\
\text { dalam pengecetan trotoar }\end{array}$ & $\begin{array}{l}\text { Perbaikan toroar menjadi batu } \\
\text { granit } \\
\text { Penyelenggaraan BCN setiap } 2 \\
\text { minggu } 1 \text { kali }\end{array}$ \\
\hline & $\begin{array}{l}\text { Pelestarian bangunan } \\
\text { tua }\end{array}$ & $\begin{array}{l}\text { Pemerintah Kota Bandung } \\
\text { (Distarcip) }\end{array}$ & $\begin{array}{l}\text { Masyarakat (pemilik toko) } \\
\text { menjadi pelaku utama } \\
\text { dalam pelestarian } \\
\text { bangunan tua }\end{array}$ & $\begin{array}{l}\text { Dilakukan pengecetan terhadap } \\
\text { bangunan sepanjang jalan Braga }\end{array}$ \\
\hline & $\begin{array}{l}\text { Pemasangan bangku } \\
\text { dan ornament hias } \\
\text { (batu hias, tanaman } \\
\text { hias, lampu hias) }\end{array}$ & $\begin{array}{l}\text { Pemerintah Kota Bandung } \\
\text { ( Diskamtam) }\end{array}$ & $\begin{array}{l}\text { Hanya pemberian } \\
\text { informasi }\end{array}$ & $\begin{array}{l}\text { Pemasangan dilakukan sebagai } \\
\text { penunjang kosep citywalk }\end{array}$ \\
\hline & Penataan parkir & $\begin{array}{l}\text { Pemerintah Kota Bandung } \\
\text { (Dinas PU dan Distarcip) }\end{array}$ & $\begin{array}{l}\text { Hanya pemberian } \\
\text { informasi }\end{array}$ & Pemasangan alat parkir prabayar \\
\hline & $\begin{array}{l}\text { Penyelenggaraan Braga } \\
\text { Culinary Night }\end{array}$ & $\begin{array}{l}\text { Pemerintah Kota Bandung } \\
\text { (Dinas Pariwisata) }\end{array}$ & $\begin{array}{l}\text { Masyarakat ikut serta } \\
\text { sebagai panitia kegiatan }\end{array}$ & $\begin{array}{l}\text { Dilaksanakan setiap } 2 \text { minggu } 1 \\
\text { kali }\end{array}$ \\
\hline
\end{tabular}


Teknik, 37 (1), 2016, 22

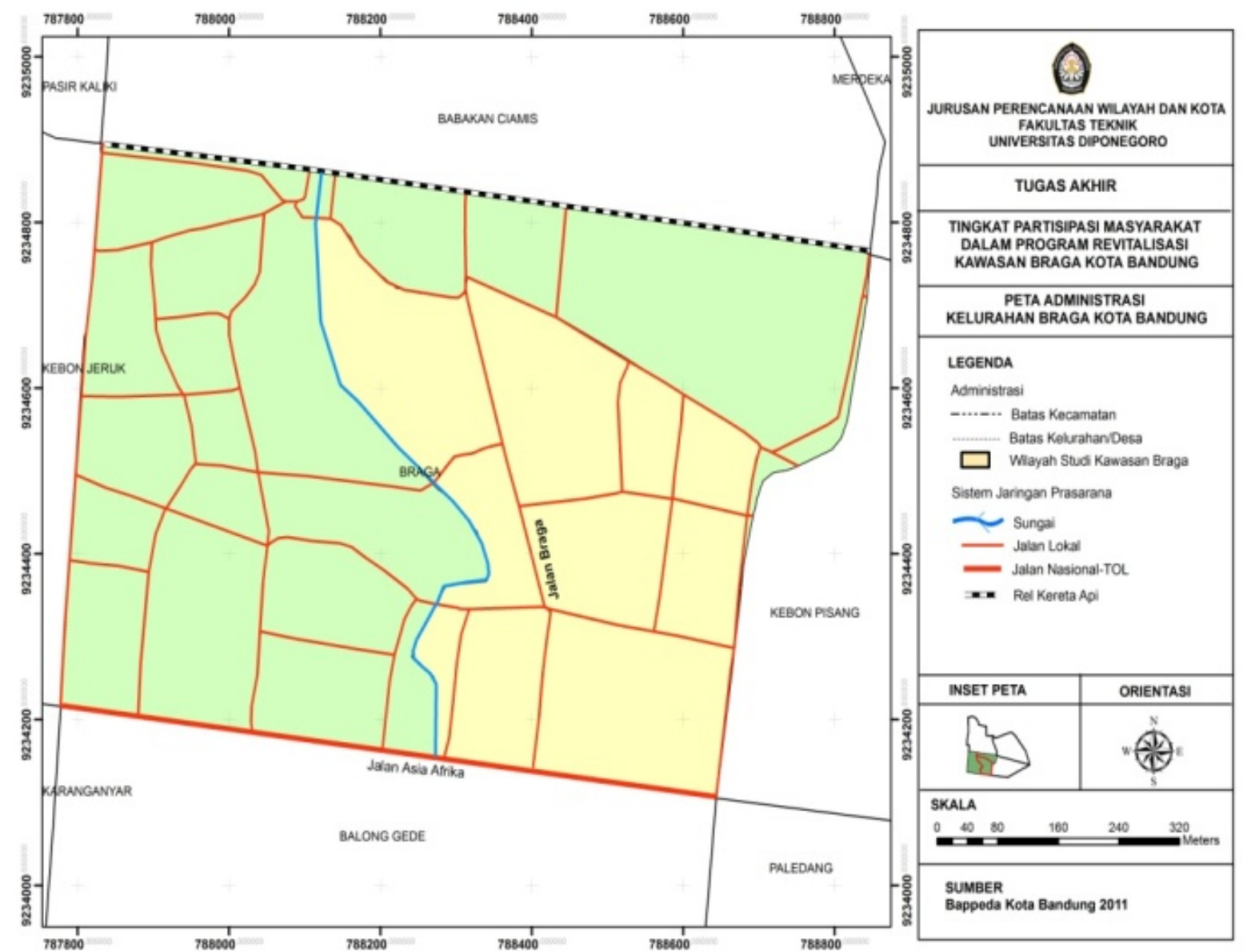

Gambar 3. Peta Administrasi Kelurahan Braga (Bappeda Kota Bandung, 2011)

Tabel 3. Perhitungan Skor Partisipasi Masyarakat dalam Revitalisasi Kawasan Braga (Hasil Analisis Peneliti, 2015)

\begin{tabular}{clc}
\hline No & \multicolumn{1}{c}{ Kategori } & Skor \\
\hline 1 & Pemahaman tentang pentingnya partisipasi dalam program & 160 \\
2 & Keikutsertaan dalam kegiatan Revitalisasi & 126 \\
3 & Intensitas pertemuan yang melibatkan masyarakat & 132 \\
4 & Keikutsertaan dalam pertemuan & 131 \\
5 & Keaktifan dalam pertemuan & 133 \\
6 & Keterlibatan dalam organisasi yang konsern dalam kemajuan Kawasan Braga & 144 \\
7 & Pemberian informasi dari Pemkot terkait Revitalisasi & 152 \\
8 & Negosiasi masyarakat dengan pemerintah terkait program & 99 \\
9 & Dukungan terhadap program revitalisasi & 175 \\
10 & Monitoring evaluasi yang dilaksanakan masyarakat terhadap program revitalsiasi & 115 \\
\hline
\end{tabular}

Tahapan selanjutnya adalah perhitungan interval untuk 5 indikator yang akan digunakan. Kelima indikator ini akan menentukan tingkat partisipasi masyarakat dalam program revitalisasi Kawasan Braga tahun 2014. Caranya adalah dengan melakukan perhitungan dari jumlah sampel 80 responden, dapat diketahui bahwa skor minimum untuk tingkat kepuasan masyarakat secara keseluruhan (80x10x1) adalah 800 dan skor maksimum (80x10x3) adalah 2400, maka interval untuk 5 indikator ((2400$800) / 5$ ) adalah 320. Sehingga dapat diketahui tingkat kepuasan masyarakatnya adalah:
- Sangat Tinggi, skor
: $2080-2400$
- Tinggi, skor
: 1760 - 2079,9
- Sedang, skor
: $1440-1759,9$
- Rendah, skor
: $1120-1439,9$ 
- Sangat Rendah, skor : 880 - 1119,9

Setelah dilakukan perhitungan skor di Tabel 3 dan telah diketahui total skor yang diperoleh adalah sebesar 1367, sehingga dapat disimpulkan bahwa tingkat kepuasan masyarakat Kawasan Braga terhadap Program Revitalisasi dikatakan rendah karena berada pada tingkat interval 1120-1439. Walaupun sudah terdapat beberapa kelompok masyarakat yang ikut terlibat dalam beberapa program revitalisasi bahkan menjadi relawan dalam menjaga kondisi Kawasan Braga sehingga tetap dapat mempertahankan eksistensinya.

Tingkat partisipasi masyarakat diukur dengan metode kuantitatif melalui penjumlahan skor dari variabel (Gambar 4). Berdasarkan jumlah skor dari semua variabel, dapat diketahui tingkat partisipasi masyarakat masuk dalam kategori tipologi delapan tangga partisipasi Arnstein (1986). Besarnya interval skor untuk menentukan kategori tingkat partisipasi masyarakat secara menyeluruh didasarkan pada skor kategori tingkat partisipasi individu dikalikan dengan jumlah sampel. Sama seperti sebelumnya, caranya adalah dengan melakukan perhitungan dari jumlah sampel 80 responden, dapat diketahui bahwa skor minimum untuk tingkat kepuasan masyarakat secara keseluruhan $(80 \times 10 \times 1)$ adalah 800 dan skor maksimum $(80 \times 10 \times 3)$ adalah 2400 , maka interval untuk 5 indikator ((2400-800)/8) adalah 200.

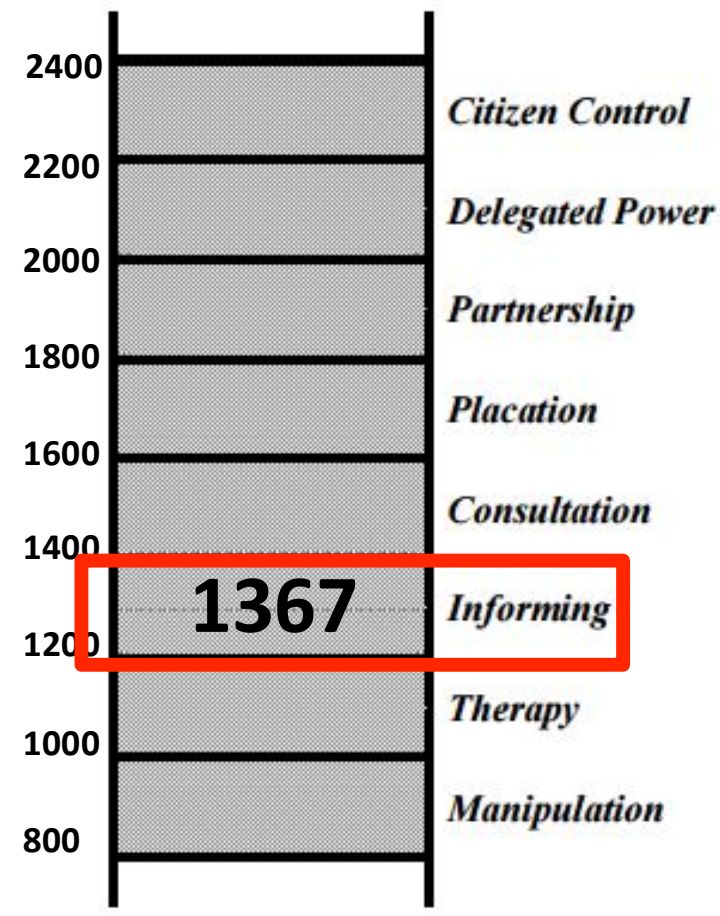

Gambar 4. Partisipasi Masyarakat Berdasarkan Tangga Partisipasi Arnestein (Hasil Analisis Peneliti, 2015)

Berdasarkan analisis Tingkat Partisipasi masyarakat diatas diketahu bahwa total skor tingkat partisipasi masyarakat dalam program revitalisasi adalah 1367 berdasarkan data kuesioner dari 80 responden. Sehingga berdasarkan tangga partisipasi
Arnstein (1986) tingkat partisipasi masyarakat dalam Program Revitalisasi jalan Braga ada pada tahap informing (pemberian informasi). Informing merupakan proses pemberian informasi kepada masyarakat tentang hak-hak mereka, tanggung jawab dan berbagai pilihan. Meskipun demikian pemberian informasi ini lebih ke informasi satu arah dari pihak pemegang kuasa kepada masyarakat. Dalam hal ini, tidak adanya kemungkinan bagi masyarakat untuk memberikan umpan balik. Dalam situasi saat itu terutama informasi diberikan pada akhir perencanaan, masyarakat hanya memiliki sedikit kesempatan untuk mempengaruhi rencana. Hal tersebut sesuai dengan hasil wawancara kepada kepala kelurahan, ketua RW dan pertanyaan kuesioner kepada masyarakat (dengan jumlah 80 responden) dimana dari hasil analisis diketahui bahwa pemerintah setiap melaksanakan program revitalisasi selalu memberkan pemberitahuan melalui lurah kemudian kepada masing masing RW dan diteruskan kepada masyarakat. Namun belum ada timbal balik yang dari masyarakat.

\subsection{Analisis Kepuasan Masyarakat}

Tingkat kepuasan masyarakat dalam analisis ini diukur dengan menggunakan metode kuantitatif dengan menggunakan Skala Likert (Tabel 4). Penggunaan Skala Likert, dapat diketahui skor masing-masing indikator dari variabel yang kita dapatkan dari jawaban responden, sehingga tingkat kepuasaj dapat diketahui melalui total skor secara keseluruhan dari seluruh variabel. Total reponden dalam penelitian ini adalah sebanyak 80 responden sebnayak 65 orang merupakan masyarakat sekitar Braga (RW 4,6 dan 8) dan 15 orang merupakan pedagang di Jalan Braga. Juga terdiri dari 30 responden wanita dan 50 responden pria.

Tabel 4. Perhitungan Skor Kepuasan Masyarakat dalam Revitalisasi Kawasan Braga (Hasil Analisis Peneliti, 2015)

\begin{tabular}{lll}
\hline No & Kategori & Skor \\
\hline 1 & Pemahaman tentang Revitalisasi & 160 \\
2 & Kodisi Kenyamanan Jalan Braga & 175 \\
3 & Kondisi Keamanan Jalan Braga & 185 \\
4 & $\begin{array}{l}\text { Pesepsi terhadap hasil perawatan } \\
\text { Bangunan Tua }\end{array}$ & 151 \\
5 & $\begin{array}{l}\text { Persepsi terhadap hasil penataan sistem } \\
\text { parkir }\end{array}$ & 144 \\
6 & $\begin{array}{l}\text { Persepsi terhadap penambahan bangku, } \\
\text { dan ornament taman hias }\end{array}$ & 171 \\
7 & $\begin{array}{l}\text { Persepsi terhadap perbaikan pedestrian dan } \\
\text { saluran air serta kondisi Jalan }\end{array}$ & 182 \\
8 & $\begin{array}{l}\text { Persepsi tentang kegiatan Braga Culinary } \\
\text { Night }\end{array}$ & 181 \\
9 & $\begin{array}{l}\text { Dampak adanya revitalisasi Jalan Braga } \\
\text { Manfaat program revitalisasi kawasan }\end{array}$ & 172 \\
\hline & Braga \\
\hline Total Skor & 196 \\
\hline
\end{tabular}


Teknik, 37 (1), 2016, 24

Tabel 4 menjelaskan tentang hasil pilihan responden terhadap 10 kategori dengan masingmasing 3 indikatornya yang menyangkut tingkat kepuasan masyarakat, maka secara kuantitatif dapat diketahui tingkat kepuasan masyarakat tersebut dengan menjumlahkan skor masing-masing indikator yang didapatkan dengan mengalikan skala masingmasing dengan frekuensi jawaban responden.

Kemudian dilakukan perhitungan interval untuk 5 indikator yang akan digunakan. Kelima indikator ini akan menentukan tingkat kepuasan masyarakat dalam program revitalisasi Kawasan Braga tahun 2014. Caranya adalah dengan melakukan perhitungan dari jumlah sampel 80 responden, dapat diketahui bahwa skor minimum untuk tingkat kepuasan masyarakat secara keseluruhan $(80 \times 10 \times 1)$ adalah 800 dan skor maksimum $(80 \times 10 \times 3)$ adalah 2400 , maka interval untuk 5 indikator $((2400-800) / 5)$ adalah 320. Sehingga dapat diketahui tingkat kepuasan masyarakatnya adalah:

- Sangat Puas, skor

$$
\begin{array}{ll}
: & 2080-2400 \\
: & 1760-2079,9 \\
: & 1440-1759,9 \\
: & 1120-1439,9 \\
: & 880-1119,9
\end{array}
$$

- Kurang Puas, skor

- Tidak Puas, skor

Setelah dilakukan perhitungan skor di Tabel 2 dan telah diketahui total skor yang diperoleh adalah sebesar 1717, sehingga dapat disimpulkan bahwa tingkat kepuasan masyarakat Kawasan Braga terhadap Program Revitalisasi dikatakan cukup puas karena berada pada tingkat interval 1440-1759,9.

\subsection{Hubungan Partisipasi dan Kepuasan dalam Program Revitalisasi Kawasan Braga}

Tingkat Partisipasi masyarakat memiliki hubungan dengan Tingkat Kepuasan Masyarakat. Hal ini ditunjukkan dengan hasil chi square $\operatorname{test}^{2}(3, \mathrm{~N}=$ $80)=38.285 ; \mathrm{p}<0,05$ atau taraf signifikansinya adalah $0,000<0,05$ sehingga Ho (tidak ada hubungan) ditolak dan H1 (ada hubungan) diterima. Maka dari Hasil Analisis diketahui bahwa ada hubungan antara Tingkat Partisipasi masyarakat dengan Kepuasan masyarakat.

Tabel 5. Hasil Chi Square Test Antara Partisipasi Masyarakat dengan Kepuasan Masyarakat (Hasil Analisis Peneliti, 2015)

\begin{tabular}{lrrc}
\hline & Value & Df & $\begin{array}{c}\text { Asymp. Sig. } \\
\text { (2-sided) }\end{array}$ \\
\hline Pearson Chi Square & $38.285^{\mathrm{a}}$ & 3 & .000 \\
Likelihood Ratio & 43.194 & 3 & .000 \\
Linear by Linear & 36.940 & 1 & .000 \\
Association & 80 & & \\
N of Valid Cases & & & \\
\hline
\end{tabular}

Tabel 5 menunjukan bahwa terdapat hubungan antara partisipasi dengan kepuasan masyarakat. Untuk mengetahui seberapa kuat hubungan tersebut dan apakah pengaruh dari hubungan tersebut baik negative maupun positif, maka dilakukan pengujian yang kedua yaitu Uji Kolerasi Spearman's Rho dan Kendall's Tau. Uji ini dilakukan karena data diatas tidak berdistribusi normal atau non parametik. Selain itu, uji ini dilakukan karena penelitian ini menggunakan data yang bersifat ordinal.

Berdasarkan hasil kolerasi Kendall's Tau. Terdapat hubungan yang signifikan antara partisipasi dengan kepuasan, $\mathrm{r}(80)=0.637 ; \mathrm{p}>0.01$. Nilai koefisien kolerasi yang menunjukan angka 0.637 menunjukan bahwa keeratan antara dua variable dalam kategori "Kuat". Begitu Juga dengan menggunakan hasil kolerasi Spearman's Rho terdapat hubungan yang signifikan antara partisipasi dengan kepuasan, $\mathrm{r}(80)=0.682 ; \mathrm{p}>0.01$. Nilai koefisien kolerasi yang menunjukan angka 0.682 menunjukan bahwa keeratan antara dua variable dalam kategori "Kuat".

Tabel 5 menunjukan nilai koefisien kolerasi positif $(+)$. Nilai koefisien kolerasi merupakan nilai yang digunakan untuk mengukur kekuatan suatu hubungan antar variable. Sehingga partisipasi dan kepuasan masyarakat memiliki hubungan yang positif. Kolerasi positif (+) menunjukann bahwa jika variable partisipasi masyarakat mengalami kenaikan maka variable kepuasan masyarakat pun akan mengalami kenaikan begitupun sebaliknya.

Penelitian mengenai hubungan antara kepuasana dan tingkat partisipasi masyarakat yang telah dilakukan memiliki asensi bahwa dalam setiap pembangunan dibutuhkan adanya partisipasi dari masyarakat sekitar. Hal ini dikarenakan persepsi masyarakat mengenai kepuasan akan pembangunan tersebut akan menentukan berhasil atau tidaknya program tersebut dilaksanakan. Masyarakat dalam hal ini yang merasakan secara langsung perbaikan ataupun perubahan yang terjadi di lingkungannya. Oleh karena itu salah satu upaya yang dilakukan pemerintah dalam revitalisasi selain pembangunan adalah melakukan evaluasi berdasarkan persepsi masyarakat kemudian barulah dilakukan perencanaan kembali terhadap jalan Braga. Penenlitian ini dapat dijadikan salah satu contoh bahwa rendahnya partisipasi masyarakat Braga mengakibatkan tingkat kepuasan masyarakat di kawasan Braga tersebut masih dalam tahap cukup puas. Sehingga pelibatan masyarakat dalam program revitalisasi ini sangatlah penting dalam menentukan kepuasan masyarakat terhadap kawasan Braga.

\section{Kesimpulan}

Proses pelaksanaan revitalisasi kawasan Braga dimulai tahun 1980-an sampai dengan terakhir di tahun 2014. Revitalisasi tahun 2014 diantaranya adalah program perbaikan trotoar dan saluran air, pelestarian bangunan tua, pemasangan bangku dan ornament hias (batu hias, tanaman hias, lampu hias), penataan parkir, penyelenggaraan braga culinary night Hasil penelitian yang dilakukan untuk mengetahui 
partisipasi masyarakat di kawasan Braga dalam program revitalisasi yang dilaksanakan adalah bahwa rendah. Apabila dikaitkan dengan tangga partisipasi tangga partisipasi Arnstein (1986) partisipasi masyarakat dalam Program Revitalisasi jalan Braga ada pada tahap Informing (Pemberian Informasi). Kepuasan masyarakat terhadap program revitalisasi Kawasan Braga diketahui bahwa tingkat kepuasannya tergolong cukup puas.

Berdasarkan menggunakan analisis cross tab maka ditemukan hasil "Partisipasi masyarakat memiliki hubungan dengan kepuasan masyarakat". Hasil uji kolerasi Spearman's Rho dan Kendall's Tau maka diketahui bahwa hubungan antara partisipasi dengan kepuasan masyarakat tergolong sedang. Berdasarkan koefisien kolerasinya maka diketahui bahwa hubungan partisipasi dan kepuasan masyarakat memiliki hubungan yang positif. Kolerasi positif $(+)$ menunjukann bahwa jika "variable partisipasi masyarakat mengalami kenaikan maka variable kepuasan masyarakat pun akan mengalami kenaikan begitupun sebaliknya"

Berdasarkan simpulan diatas maka perlu adanya kajian penilaian mengenai tingkat kepuasan masyarakat sebagai bahan evaluasi setelah dilaksanakannya suatu program revitalisasi. Terutama dalam hal ini di Kawasan Braga. Sehingga pemerintah dapat mengetahui program yang dilaksanakan sudah sesuai dengan kebutuhan masyarakat atau sudah memberikan kepuasan kepada masyarakat karena hal tersebut sangat berkaitan dengan keberhasilan program tersebut.

Rekomendasi dalam penelitian ini terutama diberikan kepada pemerintah Kota Bandung sebagai stakeholder utama dalam program revitalisasi Kawasan Braga. Pemerintah dalam hal ini perlu lebih melibatkan masyarakat minimal sampai tahap konsultasi bukan hanya pemberian informasi satu arah saja dalam program revitalisasi tersebut. Selain itu, perlu adanya suatu koordinasi antara setiap stakeholders terkait terutama dinas-dinas untuk menggatasi permasalahan Kawasan Braga sehingga bisa mencapai tujuan.

\section{Daftar Puastaka}

Adishakti, Laretna. (2002). Revitalisasi Bukan Sekedar 'Beautification'. URDI Vol. 13. www.urdi.org (Urban and Reginal Development Institute). Diunduh 28 Desember 2014

Budihardjo, Eko. (1997). Arsitektur: Pembangunan dan Konservasi. Jakarta: Penerbit Djambatan

Catanesse, Anthony James \& Snyder, James C. (1996). Perencanaan Kota (Terjemahan). Jakarta: Penerbit Erlangga
Danisworo, M dan Widjaja Martokusumo. (2000). Revitalisasi Kawasan Kota -Sebuah Catatan dalam Pengembangan dan Pemanfaatan Kawasan Kota. Jurnal URD, 13.

Dutka, Alan. (1994). AMA Handbook for Customer Satisfaction: research, planning, and implementation. Lincolnwood: NTC Business Books

Herdiansyah, Haris. (2010). Metodelogi Penelitian Kualitatif untuk ilmu-ilmu sosial. Jakarta: Salemba Humanika

International.icomos.org. (1999). Piagam Burra (1981). Terjemahan Rika Susanto \& Hasti

Kautsary, Jamilla. 2007. Bentuk Penolakan Masyarakat terhadap Implementasi Kebijakan dan Program Revitalisasi Kawasan Pecinan. Jurnal PONDASI. 13(1).

Katam. (2010). Bangunan Belanda di Jalan Braga Hanya Tersisa 73 Persen. Koran online http://news.detik.com. Diunduh 28 Desember 2014

Nazir, Moh. (1999). Metode Penelitian. Cetakan Ketiga, Jakarta, Ghalia Indonesia

Martokusumo, Widjaja. (2008). Revitalisasi dan Rancang Kota: Beberapa Catatan dan Konsep Penataan Kawasan Kota Berkelanjutan. Jurnal Perencanaan Wilayah dan Kota. 17(3), Desember 2006, 31-46

Panudju, Bambang. (1999). Pengadaan Perumahan Kota dengan Peranserta Masyarakat Berpengahsilan Rendah. Bandung: Penerbit alumni

Shirvani, Hamid. (1985). The Urban Design Process. New York: Van Nostrand Reinhold Company

Soegijoko. (2000). Urban Heritage Revitalization Impact on Urban Development. Makalah disampaikan dalam Internasional Symposium Conserving Cultural Heritage for Sustainable Social Economy and Tourism Development. Bali. Juli 2000

Sugiyono. (2010). Metode Penelitian Kuantitatif Kualitatif dan $R \& B$. Bandung: Alfabet

Surakhmad, Winarno. (1980). Pengantar Interaksi Mengajar Belajar Dasar-dasar dan Teknik Metodologi pengajaran. Bandung: Tarsito

Sufren dan Yonathan Natael. (2014). Belajar Otodidak SPSS Pasti Bisa. Jakarta: Elex Media Komputindo

Susiyanti Farma Aria. (2003). Strategi Perancangan dalam meningkatkan Vitalitas Kawasan Perdagangan Johar Semarang. Jurnal Perencanaan Wilayah dan Kota. 14(3), 47-72

Syahrie, Sugeng P. (2010). Dilema Revitalisasi Pusaka Budaya Kasus Pembangunan Braga City Walk Kota Bandung. http:// www.scribd.com. Diunduh 28 Desember 2014 